\title{
HIV Infection Among Potential Blood Donors
}

\section{Zhiburt EB* and Madzaev SR}

National Pirogov Medical Surgical Center, Moscow, Russia

\begin{abstract}
The statistics on HIV in Russia in 2013 were studied and compared with the blood service data. It was found that among different contingents the minimum detection rate of HIV infection has been registered among blood donors. Maximum detection rate of HIV among men, who have sex with men, actualizes the need for a ban on their participation in blood donation. The detection rate of HIV among donors, as well as the ratio of detection of HIV among donors and other categories surveyed indicate a lack of efficiency of formation of donor contingent of supporters of a healthy lifestyle. A direct positive correlation of HIV was detected in blood donors and region population, the volume of blood processing, as well as all volumes of blood wastage due to markers of blood borne infections except the volume due to HBs-antigen.
\end{abstract}

Keywords: HIV; Infection; Donors; Statistics; Blood; Detection; Transfusion

\section{Introduction}

HIV transmission to a recipient is the most resonant adverse effect of blood transfusion [1]. From HIV infection epidemics onset and up to 2013 inclusive, 80 cases of HIV infection transmission during transfusion of fresh frozen plasma and blood products were registered in the Russian Federation. Since 2010, two such cases have been registered annually. In 2012-2013 the key reason for infection transmission during blood transfusion was red blood cell suspension transfusion from active donors in the seronegative period (Smolensk, Kemerovo regions). In March 2013 in St. Petersburg a child was transfused with red blood cells prior to donor's HIV infection test results were received [2].

HIV infection prevention should be undertaken comprehensively as regards sources of the virus, mechanisms, routes and factors of transmission as well as sensitive population, including representatives of vulnerable groups of population [3].

It would be interesting to compare HIV detectability in donors with similar characteristics in other population groups both on regional and national scale.

\section{Materials and Methods}

The following materials have been studied:

- Main statistics on HIV infection in Russia;

- Data on HIV antibody test results;

- Data on HIV antibody test results on various subpopulation in the regions of the Russian Federation in 2013 [4].

It is worth noting that personified data on new HIV infection cases in Moscow in 2012-2013 were not given; the data includes persons who were detected in the Federal Scientific and Methodology Centre for AIDS Prevention and Control for the first time as well as the data for Moscow taken from the health monitoring form of the Russian Agency for Health and Consumer Rights.

HIV antibody test results were compared to the industry statistics on the institutions affiliate to the Ministry of Health of Russia for 2013.

The results were evaluated using descriptive statistics and correlation analysis with the level of significance of 0.05 .

\section{Results and Discussion}

The number of HIV infected persons who applied to a donor point was minimal among the groups examined (Table 1 ). However, as shown in Table 1, the number of seropositives per 100,000 of serum samples was maximum in MSM group. The possibility to lift the ban for men practicing sex with other men is widely discussed on the international level [5]. The observed maximum infection detectability rate in this group makes actual the need to introduce the same ban in Russia.

The maximum HIV detectability rate among donors is in the regions with the highest overall HIV detectability rate (Table 2).

Donors take a significant part of those who were tested for HIV: median and interquartile interval of this parameter made $14.3 \%$ (10.918.6) in 2012 and $13.3 \%$ (10.6-17.3) in 2013.

The maximum share of donors in those tested is in the regions where plasma fractioning and collection points are located (Tables 3 and 4). The share of donors in the number of HIV-positive persons is low: median and interquartile interval of this parameter made $1.3 \%$ (0.8-2.6) in 2012 and $1.4 \%(0.9-2.2)$ in 2013. The list of regions with the highest value of this parameter is quite varying (Table 5). In 2012 no HIV-positive donors were identified in 12 regions (Republic of Kalmykia, Belgorod region, Karachay-Cherkess Republic, Republic of Mari El, Republic of Sakha (Yakutia), Ryazan region, YamaloNenets Autonomous District, Voronezh region, Kamchatka, Chukot Autonomous Area, Nenets Autonomous Area). In 2013 the number of such regions reduced to 8 (Amur region, Sakhalin region, Jewish Autonomous Region, Republic of Ingooshetia, Republic of Kalmykia, Karachay-Cherkess Republic, Chukot Autonomous Area, and Nenets Autonomous Area).

The ratio of HIV detectability among donors and other categories examined indirectly may show the quality of healthy donor recruiting.

*Corresponding author: Zhiburt EB, National Pirogov Medical Surgical Center, Moscow, Russia, Tel: 915290-00-67; E-mail: ezhiburt@yandex.ru

Received November 27, 2015; Accepted January 14, 2016; Published January 18 2016

Citation: Zhiburt EB, Madzaev SR (2016) HIV Infection Among Potential Blood Donors. J Med Microb Diagn 5: 215. doi:10.4172/2161-0703.1000215

Copyright: (c) 2016 Zhiburt EB, et al. This is an open-access article distributed under the terms of the Creative Commons Attribution License, which permits unrestricted use, distribution, and reproduction in any medium, provided the original author and source are credited. 
Page 2 of 3

\begin{tabular}{|c|c|c|c|c|c|c|}
\hline \multirow{2}{*}{$\begin{array}{c}\text { Group } \\
\text { examined }\end{array}$} & \multicolumn{3}{|c|}{2012} & \multicolumn{3}{|c|}{2013} \\
\hline & $\begin{array}{c}\text { Blood serum } \\
\text { examined }\end{array}$ & HIV+ & * & $\begin{array}{l}\text { Blood serum } \\
\text { examined }\end{array}$ & HIV+ & * \\
\hline Total & $26,037,319$ & 70,744 & 271.7 & $26,826,067$ & 79,728 & 297.2 \\
\hline $\begin{array}{l}\text { Men who have } \\
\text { sex with men }\end{array}$ & 2,701 & 153 & $5,664.6$ & 2,188 & 161 & $7,358.3$ \\
\hline Drug addicts & 245,227 & 9,009 & $3,673.7$ & 238,885 & 10,037 & $4,201.6$ \\
\hline $\begin{array}{l}\text { Examined } \\
\text { during } \\
\text { epidemiologic } \\
\text { investigation }\end{array}$ & 158,141 & 6,332 & $4,004.0$ & 176,092 & 6,700 & $3,804.8$ \\
\hline $\begin{array}{l}\text { Persons in } \\
\text { detention }\end{array}$ & 415,707 & 8,589 & $2,066.1$ & 398,807 & 8,953 & $2,244.9$ \\
\hline $\begin{array}{l}\text { People with } \\
\text { sexually- } \\
\text { transmitted } \\
\text { infections }\end{array}$ & 897,260 & 3,857 & 429.9 & 886,168 & 4,337 & 489.4 \\
\hline $\begin{array}{l}\text { People } \\
\text { examined due } \\
\text { to clinical signs }\end{array}$ & $5,724,621$ & 18,060 & 315.5 & $5,914,421$ & 21,744 & 367.6 \\
\hline Others & $9,557,200$ & 17,157 & 179.5 & $10,147,879$ & 19,641 & 193.5 \\
\hline $\begin{array}{l}\text { Foreigners } \\
\text { examined }\end{array}$ & $1,248,832$ & 1,944 & 155.7 & $1,501,247$ & 2,116 & 140.9 \\
\hline $\begin{array}{l}\text { Pregnant } \\
\text { women }\end{array}$ & $5,138,303$ & 6,449 & 125.5 & $5,223,644$ & 6,972 & 133.5 \\
\hline $\begin{array}{l}\text { Medical staff } \\
\text { working with } \\
\text { HIV-positive } \\
\text { patients or } \\
\text { materials } \\
\text { containing HIV }\end{array}$ & 451,312 & 162 & 35.9 & 455,737 & 166 & 36.4 \\
\hline Donors & $3,446,847$ & 976 & 28.3 & $3,382,246$ & 1,017 & 30.1 \\
\hline
\end{tabular}

Table 1: Number of new HIV infection cases among various categories of examined persons in Russia in 2012 - 2013.

\begin{tabular}{|c|c|c|c|}
\hline \multicolumn{2}{|c|}{ All groups } & \multicolumn{2}{c|}{ Donors } \\
\hline RF$^{* *}$ constituent territory & $*$ & RF constituent territory & $*$ \\
\hline Kemerovo region & $1,291.5$ & Tomsk region & 109.2 \\
\hline Tomsk region & 951.0 & Kemerovo region & 93.1 \\
\hline Sverdlovsk region & 883.6 & Novosibirsk region & 83.8 \\
\hline Samara region & 812.5 & Samara region & 68.6 \\
\hline Novosibirsk region & 790.0 & Altai Territory & 67.9 \\
\hline Irkutsk region & 726.6 & Tver region & 67.6 \\
\hline Perm region & 621.1 & Irkutsk region & 62.4 \\
\hline Leningrad region & 603.6 & Republic of Bashkortostan & 54.7 \\
\hline St. Petersburg & 531.2 & Ulyanovsk region & 53.7 \\
\hline Orenburg region & 524.6 & St. Petersburg & 52.9 \\
\hline
\end{tabular}

Note: *number of seropositive per 100,000 of serum samples examined; RF:

Russian Federation

Table 2: Regions with the highest HIV infected detectability in 2013.

\begin{tabular}{|l|l|l|l|}
\hline \multicolumn{2}{|c|}{$\mathbf{2 0 1 2}$} & \multicolumn{2}{c|}{$\mathbf{2 0 1 3}$} \\
\hline RF constituent territory & \% & \multicolumn{1}{c|}{ RF constituent territory } & $\%$ \\
\hline Kirov region & 41.7 & Tyumen region & 35.3 \\
\hline Ivanovo region & 30.9 & Ivanovo region & 34.1 \\
\hline Lipetsk region & 27.7 & Kirov region & 30.6 \\
\hline Yaroslavl region & 27.6 & Yaroslavl region & 26.2 \\
\hline Republic of Mordovia & 25.9 & Jewish Autonomous Region & 25.1 \\
\hline Jewish Autonomous Region & 24.9 & Lipetsk region & 24.2 \\
\hline Tyumen region & 23.1 & Republic of Mordovia & 23.9 \\
\hline Republic of Karelia & 21.5 & Republic of Karelia & 22.1 \\
\hline Pskov region & 21.5 & Arkhangelsk region & 20.6 \\
\hline Sverdlovsk region & 21.4 & Altai Territory & 19.9 \\
\hline
\end{tabular}

Table 3: Regions with the highest number of donors among HIV examined in 2012 and 2013.

\begin{tabular}{|c|c|c|c|}
\hline \multicolumn{2}{|c|}{2012} & \multicolumn{2}{|c|}{$\mathbf{2 0 1 3}$} \\
\hline RF constituent territory & $\%$ & RF constituent territory & $\%$ \\
\hline Bryansk region & 8.8 & Moscow region & 8.6 \\
\hline Kamchatka & 8.4 & Chukot Autonomous Area & 8.1 \\
\hline Kabardino-Balkarian Republic & 8.2 & Bryansk region & 8.0 \\
\hline Chukot Autonomous Area & 8.1 & Kamchatka & 7.5 \\
\hline Primorsky Kray & 7.8 & Primorsky Kray & 7.5 \\
\hline Volgograd region & 7.6 & Volgograd region & 7.4 \\
\hline Transbaikal Territory & 6.8 & Transbaikal Territory & 7.4 \\
\hline Republic of Tatarstan & 6.5 & Republic of Tatarstan & 5.7 \\
\hline Moscow & 5.5 & Moscow & 4.5 \\
\hline Republic of Ingooshetia & 4.2 & Republic of Ingooshetia & 4.5 \\
\hline
\end{tabular}

Table 4: Regions with the lowest number of donors among HIV examined in 2012 and 2013.

\begin{tabular}{|c|c|c|c|}
\hline \multicolumn{2}{|c|}{$\mathbf{2 0 1 2}$} & $\mathbf{2 0 1 3}$ \\
\hline RF constituent territory & $\%$ & $\begin{array}{c}\text { RF constituent } \\
\text { territory }\end{array}$ & $\%$ \\
\hline Republic of Tuva & 7.7 & Republic of Tuva & 15.4 \\
\hline Orel region & 7.6 & Chuvash Republic & 6.5 \\
\hline Amur region & 6.7 & Republic of Khakassia & 5.4 \\
\hline Republic of Altai & 6.3 & Yaroslavl region & 4.4 \\
\hline Sakhalin region & 5.4 & Astrakhan region & 3.7 \\
\hline Republic of North Ossetia & 5.1 & Republic of Karelia & 3.7 \\
\hline Magadan region & 4.9 & Chechen Republic & 3.3 \\
\hline Kaluga region & 4.9 & Kamchatka & 3.3 \\
\hline Chuvash Republic & 4.5 & Tambov region & 3.1 \\
\hline Chechen Republic & 4.3 & Kirov region & 2.9 \\
\hline
\end{tabular}

Table 5: Regions with the highest number of HIV positive donors in 2012 and 2013.

\begin{tabular}{|c|c|c|c|}
\hline \multicolumn{1}{|c|}{2012} & \multicolumn{2}{|c|}{2013} \\
\hline RF constituent territory & $\%$ & RF constituent territory & $\%$ \\
\hline Republic of Ingooshetia & 51.6 & Republic of Tuva & 87.4 \\
\hline Chechen Republic & 45.7 & Chuvash Republic & 44.0 \\
\hline Republic of Altai & 45.4 & Kamchatka & 42.7 \\
\hline Kaluga region & 43.2 & Chechen Republic & 32.1 \\
\hline Magadan region & 42.1 & Republic of Khakassia & 31.7 \\
\hline Kabardino-Balkarian Republic & 40.0 & Republic of Adygeya & 28.2 \\
\hline Republic of Tuva & 37.4 & Astrakhan region & 22.5 \\
\hline Orel region & 35.9 & Voronezh region & 22.1 \\
\hline Republic of North Ossetia & 32.0 & Stavropol region & 22.0 \\
\hline Amur region & 30.0 & Republic of Dagestan & 19.9 \\
\hline
\end{tabular}

Table 6: Regions with the highest ratio of HIV detectability among donors and other categories examined in 2012 and 2013.

Median and interquartile interval of this parameter made $7.9 \%$ (4.515.7) in 2012 and $9.0 \%(5.9-13.1)$ in 2013. In the regions with the highest value for this parameter, special attention should be paid to recruitment of donors without any HIV infection risk (Table 6).

The correlation relationship of HIV detectability in donors and other groups examined (Table 7) demonstrates epidemic process similarity among potential donors and the population in general, save for those who were examined during epidemiologic investigation and foreign subjects.

The drawback of this study is generalization of the results of new and regular donor examination. Usually the blood service identifies two infection safety indicators: blood transmission infection incidence and occurrence rate. Incidence, or prevalence, is the number of cases of a certain disease among the population at a certain moment. In blood transfusion it means the number of diseases among new donors (usually, per annum). 


\begin{tabular}{|c|c|c|c|c|}
\hline \multirow{2}{*}{ Group examined } & \multicolumn{2}{|c|}{2012} & \multicolumn{2}{|c|}{2013} \\
\hline & $r$ & $\mathbf{p}$ & $r$ & $\mathbf{p}$ \\
\hline Non-donors & 0.71 & $<0.001$ & 0.82 & $<0.001$ \\
\hline People examined due to clinical signs & 0.65 & $<0.001$ & 0.80 & $<0.001$ \\
\hline Pregnant women & 0.68 & $<0.001$ & 0.79 & $<0.001$ \\
\hline Drug addicts & 0.51 & $<0.001$ & 0.69 & $<0.001$ \\
\hline People with sexually-transmitted infections & 0.57 & $<0.001$ & 0.52 & $<0.001$ \\
\hline Persons in detention & 0.28 & $<0.05$ & 0.47 & $<0.001$ \\
\hline $\begin{array}{l}\text { Medical staff working with HIV-positive patients } \\
\text { or materials containing HIV }\end{array}$ & 0.28 & $<0.05$ & 0.24 & $<0.05$ \\
\hline Examined during epidemiologic investigation & 0.05 & $>0.05$ & 0.11 & $>0.05$ \\
\hline Foreign subjects examined & 0.11 & $>0.05$ & 0.10 & $>0.05$ \\
\hline
\end{tabular}

Table 7: Correlation relationship of HIV detectability in donors and other groups examined.

\begin{tabular}{|l|c|}
\hline \multicolumn{1}{|c|}{ Parameter } & r \\
\hline Blood rejection due to ALT, I & 0.58 \\
\hline Absolute rejection, I & 0.57 \\
\hline Blood rejection due to syphilis, I & 0.49 \\
\hline Blood rejection due to other reasons, I & 0.48 \\
\hline Blood plate concentrates obtained, doses & 0.46 \\
\hline Red blood cells produced, I & 0.45 \\
\hline Plasma spent for blood components, I & 0.44 \\
\hline Blood rejection due to HIV, I & 0.44 \\
\hline Blood rejection due to HCV, I & 0.43 \\
\hline Cell production for blood components, I & 0.41 \\
\hline Cell production by centrifugation, I & 0.40 \\
\hline Cell production from blood, I & 0.40 \\
\hline Population of the RF constituent territory & 0.40 \\
\hline Positions involved in blood collection & 0.40 \\
\hline
\end{tabular}

Table 8: The strongest $(r>0.39)$ correlation relationship of HIV detectability in donors with other donorship parameters in $2013(p<0.05)$.

Occurrence rate is the number of cases of a disease occurring during a certain period of time in a certain population. In blood transfusion it means disease finding in regular donors [6].

In this study it is not possible to differentiate between the results for new and regular donors.

HIV detectability in donors demonstrates positive correlation with all parameters of blood rejection rate using blood transmitted infection markers (Table 8 ). The only exception is the blood rejection rate on HBs antigen, where no correlation is present. We may assume the identity of transmission mechanisms of HIV, HCV and syphilis as well as liver lesions as a result of alcohol consumption among persons with deviant behaviour who apply to a donor point. Positive HIV test results are more common for large regions and centres with the highest blood collection rates.

\section{Conclusions}

1. It was found that among different contingents the minimum detection rate of HIV infection in regions of the Russian Federation in 2013 has been registered among blood donors.

2. Maximum detection rate of HIV among men practicing sex with men actualizes the need for a ban on their participation in blood donation.

3. The detection rate of HIV among donors, as well as the ratio of detection of HIV among donors and other categories surveyed indicate a lack of efficiency of formation of donor contingent of supporters of a healthy lifestyle.

4. A direct positive correlation detection of HIV in blood donors and region population, the volume of blood processing, as well as all volumes of blood wastage due to markers of bloodborne infections except the volume due to HBs-antigen.

\section{References}

1. Bruhn R, Lelie N, Custer B, Busch M, Kleinman S (2013) Prevalence of human immunodeficiency virus RNA and antibody in first-time, lapsed, and repeat blood donations across five international regions and relative efficacy of alternative screening scenarios. International NAT Study Group. Transfusion 53: $2399-412$.

2. Letter from the Russian Agency for Health and Consumer Rights dated 20.06.2013 No. 01/6939-13-32 "On the improvement in the efficiency of antiepidemic measures aimed at HIV infection prevention during medical treatment".

3. Minga A, Dohoun L, Abo Y, Coulibaly A, Konaté S, et al. (2010) Risk behaviors in volunteer blood donors who seroconverted for HIV, Abidjan, Côte d'Ivoire 1997 to 2005. Transfusion 50: 888-93.

4. HIV infection. Information Circular (2014) No. 39 (http://www.hivrussia.ru/files/ bul_39.pdf - as of 05.12.2014).

5. Benjamin RJ, Bianco C, Goldman M, Seed CR, Yang H, et al. (2011) Deferral of males who had sex with other males. Vox Sang 101: 339-67.

6. Schreiber GB, Busch MP, Kleinman SH, Korelitz JJ (1996) The risk of transfusion-transmitted viral infections. N Engl J Med 334: 1685-90. 